\title{
Serotonin IA Receptor Binding and Treatment Response in Late-Life Depression
}

\author{
Carolyn Cidis Meltzer*, I,2,3, Julie C Price', Chester A Mathis', Meryl A Butters'², Scott K Ziolko', \\ Eydie Moses-Kolko', Sati Mazumdar,4, Benoit H Mulsant ${ }^{2}$, Patricia R Houck', Brian J Lopresti', \\ Lisa A Weissfeld ${ }^{4}$ and Charles F Reynolds ${ }^{2,3,5}$ \\ 'Department of Radiology, University of Pittsburgh, Pittsburgh, PA, USA; ${ }^{2}$ Department of Psychiatry, University of Pittsburgh, Pittsburgh, PA, USA; \\ ${ }^{3}$ Department of Neurology, University of Pittsburgh, Pittsburgh, PA, USA; ${ }^{4}$ Department of Biostatistics, University of Pittsburgh, Pittsburgh, PA, \\ USA; ${ }^{5}$ Department of Neuroscience, University of Pittsburgh, Pittsburgh, PA, USA
}

\begin{abstract}
Depression in late life carries an increased risk of dementia and brittle response to treatment. There is growing evidence to support a key role of the serotonin type IA (5-HT IA) receptor as a regulator of treatment response, particularly the 5-HT IA autoreceptor in the dorsal raphe nucleus (DRN). We used [ ' C]WAY 100635 and positron emission tomography (PET) to test our hypothesis that 5-HTIA receptor binding in the DRN and prefrontal cortex is altered in elderly depressives and that these measures relate to treatment responsivity. We studied 17 elderly subjects with untreated (nonpsychotic, nonbipolar) major depression (four men, 13 women; mean age: $71.4 \pm 5.9$ ) and 17 healthy control subjects (eight men, nine women; mean age: $70.0 \pm 6.7$ ). Patients were subsequently treated with paroxetine as part of a clinical trial of maintenance therapies in geriatric depression. [ ' C]WAY 100635 PET imaging was acquired and binding potential (BP) values derived using compartmental modeling. We observed significantly diminished [ ' $\mathrm{C}$ ]WAY I00635 binding in the $\mathrm{DRN}$ in depressed $(\mathrm{BP}=2.31 \pm 0.90)$ relative to control $(\mathrm{BP}=3.69 \pm 1.56)$ subjects $(p=0.0016)$. Further, the DRN BP was correlated with pretreatment Hamilton Depression Rating Scores $(r=0.60, p=0.014)$ in the depressed cohort. A trend level correlation between DRN binding and time to remission $(r=0.52, p=0.067)$ was observed in the 14 depressed patients for whom these data were available. Our finding of decreased [ ' ' C]WAY 100635 binding in the brainstem region of the DRN in elderly depressed patients supports evidence of altered 5- $\mathrm{HT}_{\text {IA }}$ autoreceptor function in depression. Further, this work indicates that dysfunction in autoreceptor activity may play a central role in the mechanisms underlying treatment response to selective serotonin reuptake inhibitors in late-life depression. Neuropsychopharmacology (2004) 29, 2258-2265, advance online publication, 13 October 2004; doi: I 0. I 038/sj.npp. 1300556
\end{abstract}

Keywords: depression; serotonin; brain; emission tomography

\section{INTRODUCTION}

Late-life depression, with a prevalence of $1-20 \%$ of persons 60 years of age or older, carries substantial and growing public health implications for the aging United States population (Blazer et al, 1987). Work from our institution and others has demonstrated success in treating late-life depression (Alexopoulos et al, 1996; Bump et al, 2001; Gildengers et al, 2002), but has also found that the response to antidepressant therapy may be brittle and carry an increased risk of chronicity in elders (Dew et al, 1997). Biological age-associated changes may also contribute to the unique challenges of depression treatment in the elderly.

Extensive evidence supports a key role of serotonergic dysfunction in the development of major depression, and

*Correspondence: CC Meltzer, University of Pittsburgh Medical Center, PUH D-132, 200 Lothrop Street, Pittsburgh, PA 152132582, USA, Tel: + I 412647 3553, Fax: + | 4126470738

E-mail: meltzercc@msx.upmc.edu

Received I4 December 2003; revised 24 March 2004; accepted II May 2004 there has been increased attention on the serotonin $1 \mathrm{~A}$ $\left(5-\mathrm{HT}_{1 \mathrm{~A}}\right)$ receptor as a regulator of treatment response. The central 5-HT neurotransmitter system encompasses an extensive network of ascending projections from the brainstem raphe nuclei to cortical and limbic brain regions. Preclinical evidence suggests that several antidepressant agents downregulate the cortical $5 \mathrm{HT}_{1 \mathrm{~A}}$ receptor (Stahl, 1994; Stahl et al, 1993), which may be an important mechanism indicative of clinically successful antidepressant therapy (Stahl, 1992). Particular emphasis also has been placed on the modulatory role of the $5-\mathrm{HT}_{1 \mathrm{~A}}$ autoreceptor in the dorsal raphe nucleus (DRN). The well-described approximately 2-week delay in achieving clinical efficacy with SSRIs and other antidepressants has been attributed to the time needed to desensitize the $5-\mathrm{HT}_{1 \mathrm{~A}}$ autoreceptormediated inhibitory feedback mechanism (Kreiss and Lucki, 1995; Li et al, 1996) (Blier and Bergeron, 1995).

Limited in vivo human studies of the $5-\mathrm{HT}_{1 \mathrm{~A}}$ receptor in major depression indicate reductions in binding in the midbrain and cortical areas in young and midlife subjects (Drevets et al, 1999, 2000; Sargent et al, 2000). The study 
conducted by Drevets et al (2000) focused on a unique cohort of highly selective familial mood disorder patients. Work by Sargent et al (2000) included both medication free and subjects on antidepressant medication. Contrary to the data from these studies, postmortem work by Stockmeier et al (1998) indicated elevated rather than depressed binding of $\left[{ }^{3} \mathrm{H}\right] 8-\mathrm{OH}-\mathrm{DPAT}$ in the midbrain of suicide victims with major depression.

There are also few data on how aging may affect the function of the serotonergic system, particularly the $5-\mathrm{HT}_{1 \mathrm{~A}}$ receptor, and its relationship to depression (Tsukada et al, 2001). Indeed, age-associated changes in serotonergic function could have a substantial impact on the capacity of the elderly to resist depression and to respond to serotonergically mediated antidepressant pharmacotherapy. Some postmortem studies (Arango et al, 1997; Dillon et al, 1991; Marcusson et al, 1984a; Matsubara et al, 1991), but not others (Cheetham et al, 1990; Palego et al, 1997) have found aging effects in $5-\mathrm{HT}_{1 \mathrm{~A}}$ receptor density. Two PET studies using the selective $5-\mathrm{HT}_{1 \mathrm{~A}}$ receptor antagonist $\left[{ }^{11} \mathrm{C}\right]$ WAY 100635 have shown an influence of age on 5$\mathrm{HT}_{1 \mathrm{~A}}$ binding (Meltzer et al, 2001; Tauscher et al, 2001). Meltzer et al (2001) examined subjects across the adult lifespan and noted an aging decline in men, but not women. Conversely, in a men-only study, Rabiner et al (2002) found no decline in [ ${ }^{11} \mathrm{C}$ ]WAY 100635 binding within the relatively narrow age range of 24-53 years. Similarly, Parsey et al (2002) observed no effect of age on $5-\mathrm{HT}_{1 \mathrm{~A}}$ receptor. Differing conclusions reached in studies to date may be, in part, accounted by the restricted range of ages in several studies (Rabiner et al, 2002; Tauscher et al, 2001) and methodological variation, particularly in whether arterial blood sampling was performed and tracer kinetic modeling approaches, across studies.

In this study, we applied quantitative PET imaging techniques and $\left[{ }^{11} \mathrm{C}\right] \mathrm{WAY} 100635$ to test our hypothesis that $5-\mathrm{HT}_{1 \mathrm{~A}}$ receptor binding in the $\mathrm{DRN}$ and prefrontal cortex would be altered in elderly depressed patients, and further would relate to clinical measures of antidepressant treatment response variability with SSRIs.

\section{METHODS AND MATERIALS}

\section{Subject Selection}

In all, 17 untreated, elderly patients with current episodes of major depression and a comparison group of 17 healthy, elderly control subjects were recruited for study participation in collaboration with the Mental Health Intervention Research Center for Late-Life Mood Disorders at the University of Pittsburgh. Nine of the 17 patients had recurrent depression, while eight subjects had singleepisode depression. Clinical and demographic information are shown in Table 1.

Evaluation included a psychiatric interview using the Structured Clinical Interview for Diagnostic and Statistical Manual of Mental Disorders (1994) (DSM-IV) (First et al, 1995). The Mini-Mental State Examination (MMSE) (Folstein et al, 1985) and Mattis Dementia Rating Scale (Mattis, 1976) were administered to evaluate cognitive status. Patients and controls had routine physical examinations and blood tests (including thyroid hormone levels). All depressed subjects met DSM-IV criteria for current major depressive episode (nonpsychotic) (1994). Consensus expert evaluation confirmed the diagnosis of depression. Criteria included a score of 15 or greater on the 17-item Hamilton Depression Rating Scale (HDRS) (Hamilton, 1960). Individuals with unstable medical illness, substance abuse over the past year, history of significant head trauma (defined as loss of consciousness for greater than $30 \mathrm{~min}$ ) or active malignancy, and those taking psychotropic or other medications with known central nervous system effects including beta-blockers, were not studied. Subjects were also instructed to refrain from use of nonprescription cold preparations for 1 week before the PET study. Patients were free of antidepressant medications, including St John's Wort, for a minimum of 2 weeks (an extended washout period of 8 weeks was used for fluoxetine due to the prolonged pharmacokinetic half-life of this SSRI and its metabolites). Of the group of 17 patients, only seven persons were taking antidepressant medication at the time of study referral. Among these seven patients, there was a median of 22 days (range: 14-26) between the time of discontinuing antidepressant agents (including klonopin, remeron, zyprexa, effexor, wellbutrin, trazodone, celexa, Zoloft, and St John's Wort) and the PET session. For healthy control subjects, additional exclusion criteria included a history of neurological or psychiatric disease and/or a firstdegree relative with a psychiatric or neurodegenerative disorder. A HDRS score of 6 or less was required to exclude depressive symptomatology among the control subjects. Immediately before the PET study, all subjects underwent a urine screening examination for the presence of psychoactive drugs. Two healthy subjects and four depressed women were on chronic hormone replacement therapy at the time of study.

Following the PET study, 15 of the 17 patients were treated for depression with paroxetine as part of an ongoing clinical trial of maintenance therapy in geriatric depression. The remaining two patients refused therapy. We initiated paroxetine dosing at $10 \mathrm{mg} /$ day, increasing by $10 \mathrm{mg} /$ day every 2 weeks as needed. For this analysis, treatment

Table I Subject Characteristics

\begin{tabular}{lccccccc}
\hline & N & $\begin{array}{c}\text { Gender (men/ } \\
\text { women) }\end{array}$ & $\begin{array}{c}\text { Mean age } \pm \text { s.d. } \\
\text { (years) }\end{array}$ & $\begin{array}{c}\text { Mean years of } \\
\text { education } \pm \text { s.d. (years) }\end{array}$ & MMSE \pm s.d. & $\begin{array}{c}\text { Mattis } \pm \text { s.d. } \\
\text { Hamiltem }\end{array}$ s.d. \\
\hline Depressed patients & 17 & $4 / 13$ & $71.4 \pm 5.9$ & $14.0 \pm 3.0$ & $28.5 \pm 2.0$ & $134.8 \pm 10.2$ & $18.1 \pm 2.7 * 3$ \\
Healthy controls & 17 & $8 / 9$ & $70.0 \pm 6.7$ & $15.8 \pm 2.4$ & $28.9 \pm 1.0$ & $139.3 \pm 4.1$ & $1.5 \pm 1.8$ \\
\hline
\end{tabular}

$* P \leqslant 0.05$. 
response was reflected by a time to remission measure, which was calculated as the number of weeks from the onset of therapy until achieving an HDRS score of 7 by weekly testing. One patient left the treatment trial prematurely at 4 weeks with no therapeutic response and thus was excluded from treatment response calculations.

All subjects provided written informed consent prior to study entry, as approved by the University of Pittsburgh Institutional Review Board and Radioactive Drug Research Committee.

\section{Imaging Acquisition and Analysis}

The radiosynthesis of [carbonyl- ${ }^{11} \mathrm{C}$ ]WAY 100635 was performed as previously described (McCarron et al, 1996; Meltzer et al, 2001). PET scans were acquired on a ECAT $\mathrm{HR}+\mathrm{PET}$ scanner (CTI PET Systems, Knoxville, TN) in three-dimensional (3D) mode (63 transaxial planes $(2.4-\mathrm{mm}$ thickness); in-plane resolution $=4.1 \mathrm{~mm}$ full-width at halfmaximum (FWHM) over a 15.2-cm field-of-view). Subjects were positioned parallel to the canthomeatal line and the entire brain was included in the scan. Following a brief transmission scan, emission imaging immediately followed intravenous injection of $13.8 \pm 2.0 \mathrm{mCi}\left[{ }^{11} \mathrm{C}\right] \mathrm{WAY} 100635$. PET scanning was performed for $60 \mathrm{~min}$. (An additional $30 \mathrm{~min}$ for a total of $90 \mathrm{~min}$ of postinjection emission data was collected in four controls and 10 patients). A Neuroinsert (CTI PET Systems, Knoxville, TN) placed in the camera gantry was used to reduce random coincidences (Weinhard, 1998). Head movement was minimized by the use of a thermoplastic mask and headholder system. A 10min transmission scan was acquired using rotating rods of $68 \mathrm{Ge} / 68 \mathrm{Ga}$ immediately prior to the administration of $\left[{ }^{11} \mathrm{C}\right]$ WAY 100635 for attenuation correction of emission data. PET data were also corrected for radioactive decay and scatter using a model-based approach (Watson et al, 1997). PET image reconstruction was performed using filtered back-projection (Fourier rebinning, 2D backprojection, Hann filter: kernel FWHM $=3 \mathrm{~mm}$ ) for a final reconstructed image resolution of about $6 \mathrm{~mm}$ (transverse and axial, in-house measurements, data not shown).

Dynamic arterial blood sampling was performed during emission scanning. Plasma data were corrected for the presence of radiolabeled metabolites of $\left[{ }^{11} \mathrm{C}\right]$ WAY 100635 as determined by high-performance liquid chromatography analyses.

The PET data were registered to T1-weighted volumetric spoiled gradient recalled (SPGR) magnetic resonance (MR) images for the dual purpose of guiding region-of-interest (ROI) placement and performing partial volume correction. MR images were acquired using a Sigma $1.5 \mathrm{~T}$ scanner (GE Medical Systems, Milwaukee, WI) with a standard head coil. The SPGR sequence $(\mathrm{TE}=5, \mathrm{TR}=25$, flip angle $=$ $40^{\circ}, \mathrm{NEX}=1$; section thickness $=1.5 \mathrm{~mm}$ with no intersection gap) was acquired in the coronal plane. PET-MR registration was accomplished using Automated Image Registration (Woods et al, 1998). Pixels corresponding to scalp and calvarium were removed from the SPGR MR images (Smith, 2002) to facilitate registration with the PET images.

With the exception of the brainstem area of the DRN, ROIs were hand-drawn (by a single investigator blinded to subject group) on the coregistered MR images according to anatomic landmarks using guidelines established within the laboratory and transferred to the dynamic PET data for regional sampling. ROIs were sampled on multiple consecutive MR images on which the structure was visualized (except for the occipital cortex, which was sampled on a single plane) and right and left regions were combined to reduce noise (Meltzer et al, 2001). Regions sampled included areas known to contain moderate to high $5-\mathrm{HT}_{1 \mathrm{~A}}$ receptor density and those implicated in depressive illness and the response to antidepressant therapy (Mayberg et al, 2000; Stockmeier et al, 1998). These included the hippocampus (HIP) and mesial temporal cortex (MTC, which encompassed the amygdalo-hippocampal complex and adjacent portions of the parahippocampal gyrus), lateral orbitofrontal cortex (LOF) (Brodmann area (BA) 47), pregenual anterior cingulate (PGC; BA 24/32), and subgenual cingulate (SGC; BA 25/32). In order to assess the regional specificity of our findings, an additional cortical region not implicated in mood regulation was also sampled (occipital cortex (OCC); BA 18). Since the DRN (an approximately $1.5-\mathrm{cm}$-long cylindrical structure oriented vertically in the posterior brainstem) does not have discernible borders on MR images, we used the MR to define $z$-axis landmarks from the upper pons to the midbrain on three consecutive sections (with the inferiormost plane defined by the interpeduncular cistern) (Niewenhuys et al, 1981). The brainstem region of the DRN was then sampled directly on a late summed PET image (15-60 min postinjection interval) directly over the highest area of focal tracer uptake using an 8-mm-diameter circular ROI. Owing to negligible density of $5-\mathrm{HT}_{1 \mathrm{~A}}$ receptors, the cerebellum (CER) served as the reference region reflective of free and nonspecific binding (Pazos et al, 1987). The cerebellar hemispheres were sampled on three consecutive planes centered approximately at the level of the inferior portion of the fourth ventricle. (Care was taken to avoid spill-in of adjacent occipital lobe radioactivity by sampling the cerebellum at least two sections below the inferior-most aspect of the occipital cortex). We previously performed inter-rater reliability (two raters) measures for three ROIs (CER, LOF, DRN), with intraclass correlation coefficients ranging from 0.926 to 0.998 .

Time-activity data (0-60 min postinjection) were generated from the dynamic image data for each ROI. Specific binding was assessed via the binding potential (BP) measure that corrects the regional radiotracer distribution volume $\left(\mathrm{DV}_{\mathrm{ROI}}\right)$ for the free and nonspecific radiotracer distribution as determined in a reference region. In those subjects who underwent 90 min scans, 90 min time-activity data was also produced for comparison purposes. For $\left[{ }^{11} \mathrm{C}\right] \mathrm{WAY}$ 100635 , the BP was determined by subtraction of the reference $\mathrm{DV}$ measure: $\mathrm{BP}=\left[\mathrm{DV}_{\mathrm{ROI}}-\mathrm{DV}_{\mathrm{CER}}\right]$. This measure of $\mathrm{BP}$ is dependent on plasma nonspecific binding (see (Parsey et al, 2000)). Plasma protein binding was measured in all subjects in order to consider the extent to which a group difference in BP could be influenced by this factor. In five subjects (four patients, one control), the $k_{4}$ of the CER (reference region) was near zero or negative; in these cases a two-compartment three-parameter model was used to obtain a $D V_{C E R}$ value. In four of these five subjects, the two-compartment DV values were within $4 \%$ agreement 
with three-compartment DV values; in the remaining one subject for which $k 3$ and $k 4$ were very small and negative, further supporting the need for a one-tissue compartment model (with vascular volume). For other individual ROIs, outliers (defined as regions with a negative or near negative $k_{4}$ ) were excluded from analysis. This involved five subjects (four patients, one control) in whom seven ROI BP measures generated out of a total of 238 curve fits were excluded based on these criteria.

Regional BP values were corrected for potential partial volume effects due to differential cerebral volume loss among the elderly subjects and evidence for selective prefrontal volume loss in depression (Botteron et al, 2002). For this purpose, we applied a previously validated two-component MR-based atrophy correction algorithm (Meltzer et al, 1999, 1990), as modified and routinely used in our laboratory (Meltzer et al, 2001).

\section{Statistical Analysis}

For intergroup comparisons of BP values, we used a Wilcoxon rank-sum test $(\alpha=0.05$, exact inference). A nonparametric test was used because the central limit theorem was deemed inapplicable as a result of the small sample size and violations of the assumptions of normality in the two populations. The Wilcoxon test was also applied to assess differences in age, educational level, and depression and cognitive measures between patients and healthy control subjects. Pearson's correlations were applied to examine the relationships between time to remission and $\mathrm{BP}$, and baseline HDRS and BP. For all analyses, statistical significance was set at the $p \leqslant 0.05$ level.

\section{RESULTS}

There were no significant differences in age, educational level, and MMSE or Mattis scores between the depressed and healthy control subject groups. Time to remission ranged from 2 to 14 weeks (mean: $7.1 \pm 3.9$ s.d.; median: 6.5).

We observed significantly diminished $\left[{ }^{11} \mathrm{C}\right]$ WAY 100635 binding in the DRN in depressed $(\mathrm{BP}=2.31 \pm 0.90$ s.d. $)$ relative to healthy control ( $\mathrm{BP}=3.69 \pm 1.56$ s.d.) subjects $\left(p=0.0016, W=221, n_{1}=16, n_{2}=17\right.$; Table 2). Although we selected few brain regions for study based on a priori hypotheses informed by the literature, it is worthy of note that this main study finding remains statistically significant following a conservative Bonferroni correction for multiple comparisons among seven ROIs $(p<0.007)$. The DRN BP measure was also correlated with baseline HDRS in the patients $(r=0.60, p=0.014, t=2.7947, \mathrm{df}=14)$, that is, the more severe the depression prior to therapy, the higher the DRN BP value. Further, the DRN BP in patients was positively correlated with time to remission in the 14 patients in whom treatment response information was available $(r=0.52, p=0.067, t=2.0295, \mathrm{df}=11$; Figure 1$)$, although this relationship did not reach statistical significance. Of note, there was no significant relationship between pretreatment HDRS and time to remission $(r=0.41, p=0.17, t=1.4752, \mathrm{df}=11)$.
Table 2 Regional Compartmental BP Values for Depressed Patients and Healthy Controls

\begin{tabular}{lcccc}
\hline Region & N & $\begin{array}{c}\text { Depressed mean } \\
\text { BP } \pm \text { s.d. }\end{array}$ & N & $\begin{array}{c}\text { Controls mean } \\
\text { BP } \pm \text { s.d. }\end{array}$ \\
\hline DRN & 16 & $2.45 \pm 0.87^{*} \cdot \mathrm{a}$ & 17 & $3.72 \pm 1.62$ \\
LOF & 17 & $3.81 \pm 0.7 \mid$ & 16 & $4.13 \pm 1.241$ \\
PGC & 17 & $4.57 \pm 1.43$ & 17 & $4.76 \pm 1.51$ \\
SGC & 16 & $5.09 \pm 1.271$ & 17 & $5.17 \pm 1.47$ \\
HIP & 15 & $6.45 \pm 2.47^{\mathrm{b}}$ & 17 & $7.55 \pm 4.24$ \\
MTC & 15 & $6.58 \pm 1.44^{\mathrm{b}}$ & 17 & $7.11 \pm 3.40$ \\
OCC & 17 & $2.63 \pm 0.90$ & 17 & $2.66 \pm 0.92$ \\
\hline
\end{tabular}

\section{$* P \leqslant 0.05$}

[DRN: dorsal raphe nucleus; LOF: lateral orbitofrontal cortex; PGC: pregenual cingulate; SGC: subgenual cingulate; HIP: hippocampus; MTC: mesial temporal cortex (includes hippocampus, amygdala, and parahippocampal gyrus); OCC: occipital cortex].

${ }^{a}$ Based on $N=16$ as a result of exclusion of data from one subject due to instability in the compartmental model fit for this ROI.

${ }^{b}$ Based on $N=15$ as a result of exclusion of data from two subjects due to instability in the compartmental model fit for this ROI.

No other brain regions demonstrated significantly elevated or reduced $\left[{ }^{11} \mathrm{C}\right]$ WAY 100635 binding in patients relative to healthy controls.

Cerebellar DV values tended to be higher in depressed than control subjects but no significant group difference was observed (control: $0.70 \pm 0.22$, depressed: $0.57 \pm 0.12$; Wilcoxon exact $\left.p=0.085, W=94, n_{1}=17, n_{2}=17\right)$. In the subset of subjects who had a full 90 min of postinjection emission data available, we observed high correlations in the cerebellar DV and regional BP measures calculated from 60 vs $90 \mathrm{~min}(r=0.80-0.93)$. Our data did not indicate gender differences in cerebellar DV (Figure 2).

Measures of serum protein binding of $\left[{ }^{11} \mathrm{C}\right]$ WAY 100635 were similar between the nine controls (mean: $0.085 \pm$ 0.034 s.d.) and 14 patients (mean: $0.087 \pm 0.023$ s.d.) in which these data were available and indicated no group differences.

\section{DISCUSSION}

The major findings of this study include significantly reduced binding of $\left[{ }^{11} \mathrm{C}\right]$ WAY 100635 to the brainstem 5$\mathrm{HT}_{1 \mathrm{~A}}$ autoreceptor in untreated, elderly depressed patients relative to healthy age-matched control subjects. We further observed a positive association between the magnitude of the DRN BP and severity of depression. Although this finding seems paradoxical, it may suggest a failure of adaptive mechanisms in those with more severe disease. This is consistent with a trend indicating lower DRN BPs were associated with reduced time to remission following antidepressant treatment. Our study suggests that the disturbance of $\left[{ }^{11} \mathrm{C}\right] \mathrm{WAY} 100635$ binding to the $5-\mathrm{HT}_{1 \mathrm{~A}}$ autoreceptor (DRN) may be related to time to treatment remission following paroxetine therapy, although future larger studies are needed to confirm this trend. This seemingly nonintuitive finding of reduced autoreceptor binding in depressed elders at baseline, but relatively lower DRN BPs associated with reduced time to remission with paroxetine is analogous to blood flow and glucose metabolic 


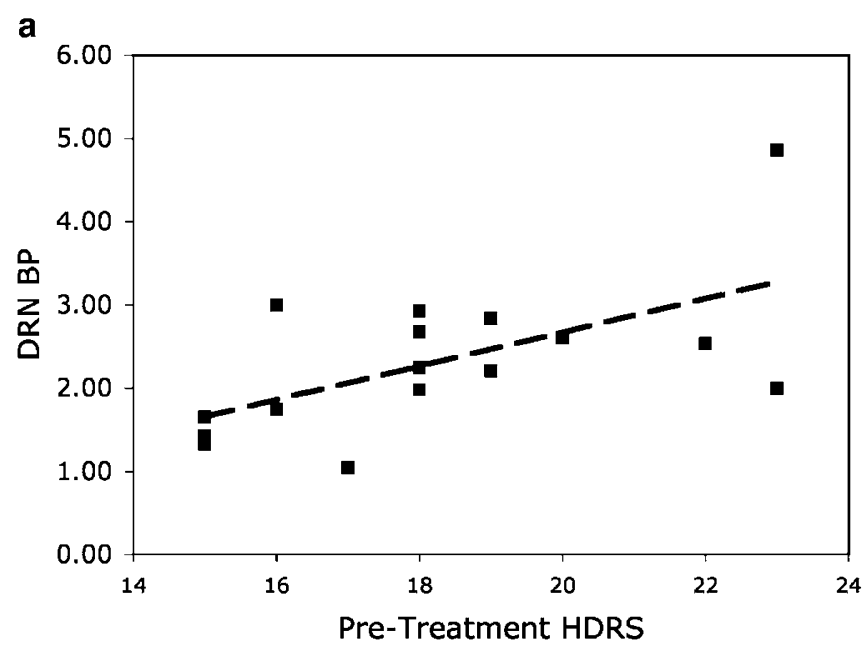

b

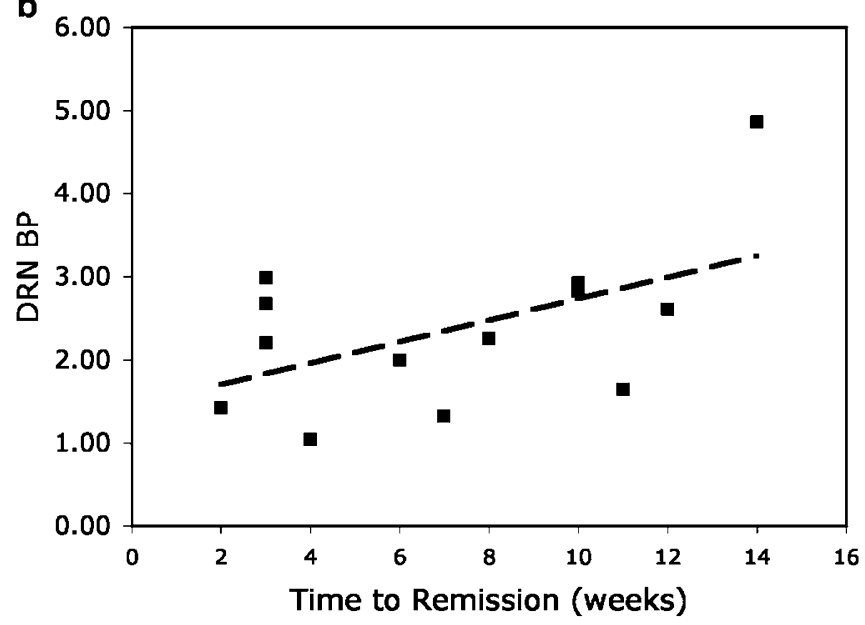

Figure I Scatter plots depicts a positive correlation between the patient DRN BP values and pretreatment HDRS $(r=0.60, p=0.014)$ (a), and a trend level correlation between DRN BP and time to remission $(r=0.52$, $p=0.067)(b)$.

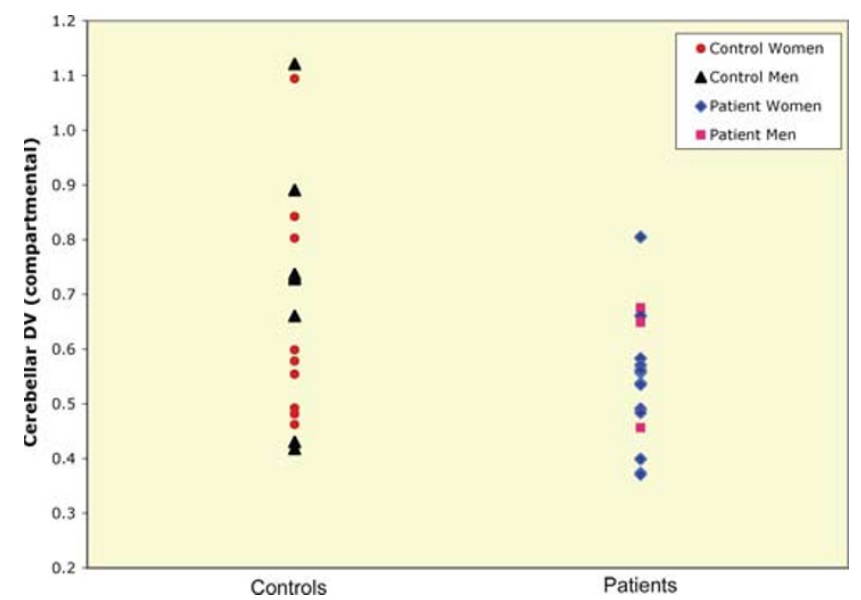

Figure 2 Scatter plot demonstrates generally higher yet overlapping cerebellar DV values in patients relative to healthy control subjects $(p=$ n.s.). No influence of gender on cerebellar DV was observed.

PET studies indicating that successful antidepressant treatment does not always result in simple normalization of baseline deficits (Kennedy et al, 2001; Mayberg et al,
2000). We did not see an abnormality in cortical prefrontal postsynaptic $5-\mathrm{HT}_{1 \mathrm{~A}}$ receptor-rich regions despite the widespread theory that reduced serotonergic input to the prefrontal cortex underlies depression.

The finding of reduced $\left[{ }^{11} \mathrm{C}\right]$ WAY 100635 binding in the brainstem region of the DRN is contrary to the hypothesis that increased inhibitory $5-\mathrm{HT}_{1 \mathrm{~A}}$ autoreceptor activity is present in depression. Indeed, Stockmeier et al (1998) observed elevated autoreceptor number in the brains of suicide victims with major depression. Two in vivo studies of $5-\mathrm{HT}_{1 \mathrm{~A}}$ function in mid-life depression also contradicted the Stockmeier et al report. Drevets et al $(1999,2000)$ found markedly diminished (42\%) $\left[{ }^{11} \mathrm{C}\right]$ WAY 100635 binding in the brainstem in depression. The cohort in this report, however, included depressed subjects with primary recurrent familial mood disorders, and the effect of diminished $\left[{ }^{11} \mathrm{C}\right]$ WAY 100635 binding in the DRN region of the brainstem was most pronounced in those with bipolar depression and in unipolar depressives with bipolar relatives. Sargent et al (2000) found more widespread reductions in $\left[{ }^{11} \mathrm{C}\right]$ WAY 100635 binding in treated and untreated depressed subjects.

Although similar findings of reduced $\left[{ }^{11} \mathrm{C}\right]$ WAY 100635 binding in the DRN have been observed previously in midlife and familial depressive subjects, we may expect depression in late life to have a different underlying pathophysiology. While the heritability of major depression occurring in young/midlife patients suggests a developmental defect in the serotonergic neuronal plexus, the heterogeneity of late-life - particularly late-onset depression - may encompass patients with an acquired insult to the 5-HT system.

One limitation in interpretation of our results is that reduced $\left[{ }^{11} \mathrm{C}\right]$ WAY 100635 binding in the DRN could result from either a decrease in density (or, possibly binding affinity) of $5-\mathrm{HT}_{1 \mathrm{~A}}$ autoreceptors or a loss of serotonergic cell bodies. Indeed, the small size of the raphe nuclei relative to the PET spatial resolution results in a systematic underestimation of tracer concentration in this structure. This effect was minimized by sampling the DRN using a small, uniform-sized ROI centered on the area of maximal tracer accumulation (Links et al, 1996). There is lack of agreement among postmortem studies as to whether there is a substantial loss of neurons in the DRN in depression. Kassir et al (1998) reported a significant reduction in the size of the DRN of suicide victims, while Underwood et al (1999) found higher neuronal number and density in the DRN in suicide. Since the DRN does not have borders that can be clearly delineated with structural imaging, MR-based morphometric techniques are not useful for identifying a potential difference in DRN size between patients and nondepressed controls in vivo. Thus, reduced DRN $\left[{ }^{11} \mathrm{C}\right]$ WAY 100635 binding in the depressed group may reflect serotonin neuronal loss or downregulation of receptor sites relative to healthy controls. Our PET results are consistent with a report by Arango et al (2001), who found no clear change in $5-\mathrm{HT}_{1 \mathrm{~A}}$ receptor density in depressed suicide victims, but suggested that a receptor index (receptor binding $\times$ volume of receptor distribution) was significantly lower in the DRN of suicides relative to controls. 
Whether the neurochemistry of late-life depression is similar to depression in midlife is an unanswered question. The clinical heterogeneity of late-life depression and treatment response in depressed elders suggests that differences may be expected (Dew et al, 1997; Lebowitz et al, 1997). Potential contributing biologic factors in the development of depression in the elderly include an imbalance of aging effects on the 5-HT neuronal system and ischemic disruption to serotonergic cell bodies or ascending afferent pathways. Aging degeneration has been observed in serotonergic circuits, such as in hippocampal 5-HT afferent fibers in rats (Venero et al, 1993). There is, however, equivocal postmortem and in vivo human postmortem evidence of aging reductions in $5-\mathrm{HT}_{1 \mathrm{~A}}$ receptor densities (Arranz et al, 1993; Marcusson et al, 1984b; Meltzer et al, 2001; Tauscher et al, 2001). Medical comorbidity and cerebrovascular effects may further influence the form and resilience of depression in late life. Links between MR-determined white matter hyperintensities and cardiovascular risk, cognitive impairment, and poorer response to antidepressant therapy also suggest that alterations in structural brain integrity may be integral to the pathophysiology and prognosis of late-life depression. Preliminary evidence in our facility in 26 elderly depressed patients demonstrated a significant correlation $(r=-0.43$, $p<0.05)$ between white matter hyperintensity burden and pretreatment Mattis ratings (Butters et al, in press), which is consistent and further supportive of a link between aging changes in brain function and late-life depression.

This study adds to growing evidence of the importance of $5-\mathrm{HT}_{1 \mathrm{~A}}$ autoreceptor activity in major depression and the efficacy of antidepressant pharmacotherapy. A report by Mayberg et al (2000) demonstrated reciprocal brainstem and cortical changes in glucose metabolism in depressed patients treated with the SSRI fluoxetine. Additionally, PET neuroreceptor studies may aid in the design and refinement of therapies targeted at reducing the interval between initiating therapy and clinical response. Although clinical trials incorporating strategies of autoreceptor blockade have yielded disappointing results to date (Berman et al, 1997), recent studies suggest that the doses and agents used in these trials were suboptimal (Martinez et al, 2000; Rabiner et al, 2000, 2001).

A limitation of this study is uneven gender matching between groups. However, our data did not indicate an influence of gender on CER DV (Figure 2), unlike Parsey et al (2002), who showed elevated CER DV in midlife women relative to men. This discrepancy may be due to the differing age ranges of subjects in the current work and that of Parsey and colleagues. We previously reported gender differences in the pattern of regional $\left[{ }^{11} \mathrm{C}\right]$ WAY 100635 binding across the adult lifespan, where men showed higher values than women the brainstem raphe region and cortex in early adulthood (Meltzer et al, 2001). These values fell in men with age, but remained stable in women. Based on this work, gender differences in BP were not expected in the age range of the current work.

Another potential confound in this study is the possible influence of chronic hormone replacement therapy in six study subjects (two controls and four patients). Based on animal studies, there is evidence that sex steroids may alter $5-\mathrm{HT}_{1 \mathrm{~A}}$ receptor function ( $\mathrm{Lu}$ and Bethea, 2002; Osterlund et al, 2000). Indeed, it has been suggested that regulation of serotonergic (particularly $5-\mathrm{HT}_{1 \mathrm{~A}}$-mediated) function may be the mechanism by which estrogen affects the development and manifestations of mood and neurodegenerative disorders. However, human studies are lacking and future work is needed to determine the influence of hormone replacement therapy on $5-\mathrm{HT}_{1 \mathrm{~A}}$ receptor activity.

\section{CONCLUSION}

Our finding of decreased $\left[{ }^{11} \mathrm{C}\right]$ WAY 100635 binding in the brainstem region of the DRN in depressed elders supports evidence of altered $5-\mathrm{HT}_{1 \mathrm{~A}}$ autoreceptor function in depression of late life. Further, this work suggests that the disturbance in autoreceptor activity may be related to depression severity and predictive of resistance to treatment with SSRIs.

\section{ACKNOWLEDGEMENTS}

This work was supported by PHS Grants MH01210, MH59945, MH64625, MH43832, MH59769, MH01684, and MH52247. We also thank Michele Bechtold, Marianne Schlernitzauer, James Ruszkiewicz, Denise Ratica, and Patricia McGowen for their vital contributions to this work.

\section{REFERENCES}

Diagnostic and Statistical Manual of Mental Disorders (1994) American Psychiatric Association: Washington, DC.

Alexopoulos G, Meyers B, Young R, Kakuma T, Feder M, Einhorn A et al (1996). Recovery in geriatric depression. Arch Gen Psychiatry 53: 305-312.

Arango V, Underwood M, Boldrini M, Tamir H, Kassir S, Hsiung $\mathrm{S}-\mathrm{C}$ et al (2001). Serotonin 1A receptors serotonin transporter binding serotonin transporter mRNA expression in the brainstem of depressed suicide victims. Neuropsychopharmacology 25: 892-903.

Arango V, Underwood M, Kassir S, Brent D, Ellis S, Bakalian M et al (1997). 5-HT1A binding alterations are more pronounced in young suicide victims alcoholics. Soc Neurosci Abstr 23: 1676.

Arranz B, Eriksson A, Mellerup E, Plenge P, Marcusson J (1993). Effect of aging in human cortical pre- postsynaptic serotonin binding sites. Brain Res 620: 163-166.

Berman RM, Darnell AM, Miller HL, Anand A, Charney DS (1997). Effect of pindolol in hastening response to fluoxetine in the treatment of major depression: a double-blind, placebo-controlled trial. Am J Psychiatry 154: 37-43.

Blazer D, Hughes D, George L (1987). The epidemiology of depression in an elderly community population. Gerontologist 27: 281-287.

Blier P, Bergeron R (1995). Effectiveness of pindolol with selected antidepressant drugs in the treatment of major depression. J Clin Psychopharmacol 15: 217-222.

Botteron KN, Raichle ME, Drevets WC, Heath AC, Todd RD (2002). Volumetric reduction in left subgenual prefrontal cortex in early onset depression. Biol Psychiatry 51: 342-344.

Bump GM, Mulsant BH, Pollock BG, Mazumdar S, Begley AE, Dew MA et al (2001). Paroxetine versus nortriptyline in the continuation and maintenance treatment of depression in the elderly. Depression Anxiety 13: 38-44.

Butters M, Whyte E, Nebes R, Begley A, Dew M, Mulsant B et al Neuropsychological functioning clinical correlates of late-life depression. Arch Gen Psychiatry (in press). 
Cheetham S, Crompton M, Katona C, Horton R (1990). Brain 5$\mathrm{HT}_{1}$ receptor binding sites in depressed suicides. Psychopharmacology 102: 544-548.

Dew MA, Reynolds III CF, Houck PR, Hall M, Buysse DJ, Frank E et al (1997). Temporal profiles of the course of depression during treatment. Predictors of pathways toward recovery in the elderly [see comments]. Arch Gen Psychiatry 54: 1016-1024.

Dillon K, Gross-Isseroff R, Israeli M, Biegon A (1991). Autoradiographic analysis of serotonin $5-\mathrm{HT}_{1 \mathrm{~A}}$ receptor binding in the human brain postmortem: effects of age and alcohol. Brain Res 554: 56-64.

Drevets WC, Frank E, Price JC, Kupfer DJ, Greer PJ, Mathis C (2000). Serotonin type-1A receptor imaging in depression. $\mathrm{Nucl}$ Med Biol 27: 499-507.

Drevets W, Frank E, Price J, Kupfer D, Holt D, Greer P et al (1999). PET imaging of serotonin $1 \mathrm{~A}$ receptor binding in depression. Biol Psychiatry 46: 1375-1387.

First M, Spitzer R, Gibbon M, Williams J (1995). Structured Clinical Interview for DSM-IV Axis 1 Disorders - patient edition $(S C I D-I / P)$. New York Psychiatric Institute: New York.

Folstein M, Anthony JC, Parhad I, Duffy B, Gruenberg EM (1985). The meaning of cognitive impairment in the elderly. $\mathrm{J} \mathrm{Am}$ Geriatr Soc 33: 228-235.

Gildengers AG, Houck PR, Mulsant BH, Pollock BG, Mazumdar S, Miller MD et al (2002). Course and rate of antidepressant response in the very old. J of Affect Disord 69: 177-184.

Hamilton M (1960). A rating scale for depression. J Neurol Neurosurg Psychiatr 23: 56-62.

Kassir S, Underwood M, Bakalian M, Mann J, Arango V (1998). 5-HT1A binding in dorsal and median raphe nuclei of suicide victims. Soc Neurosci Abstr 24: 1274.

Kennedy SH, Evans KR, Kruger S, Mayberg HS, Meyer JH, McCann $S$ et al (2001). Changes in regional brain glucose metabolism measured with positron emission tomography after paroxetine treatment of major depression. Am J Psychiatry 158: 899-905.

Kreiss DS, Lucki I (1995). Chronic administration of the 5-HT1A receptor agonist 8-OH-DPAT differentially desensitizes 5-HT1A autoreceptors of the dorsal and median raphe nuclei. Synapse 25: 107-116.

Lebowitz BD, Pearson JL, Schneider LS, Reynolds III CF, Alexopoulos GS, Bruce ML et al (1997). Diagnosis and treatment of depression in late life. Consensus statement update. JAMA 278: 1186-1190.

Links J, Zubieta J, Meltzer C, Stumpf M, Frost J (1996). Influence of heterogeneous background on 'hot object' quantitation in brain emission computed tomography. J Comput Assist Tomogr 20: 680-687.

Li Q, Muma N, Van de Kar L (1996). Chronic fluoxetine induces a gradual desensitization of 5-HT1A receptors: reductions in hypothalamic and midbrain $\mathrm{Gi}$ and $\mathrm{Go}$ proteins and in neuroendocrine responses to a 5-HT1A agonist. J Pharmacol Exp Therap 279: 1035-1042.

$\mathrm{Lu} \mathrm{N}$, Bethea C (2002). Ovarian steroid regulation of 5-HT1A receptor binding and $\mathrm{G}$ protein activation in female monkeys. Neuropsychopharmacology 27: 12-24.

Marcusson J, Morgan D, Winblad B, Finch C (1984a). Serotonin-2 binding sites in human frontal cortex and hippocampus. Selective loss of S-2A sites with age. Brain Res 311: 51-56.

Marcusson J, Oreland L, Winblad B (1984b). Effect of age on human brain serotonin (S-1) binding sites. J Neurochem 43: 1699-1705.

Martinez D, Broft A, Laruelle M (2000). Pindolol augmentation of antidepressant treatment: recent contributions from brain imaging studies. Biol Psychiatry 48: 844-853.

Matsubara S, Arora R, Meltzer H (1991). Serotonergic measures in suicide brain: $5 \mathrm{HT} 1 \mathrm{~A}$ binding sites in frontal cortex of suicide victims. J Neural Transm 85: 181-194.
Mattis S (1976). Mental status examination for organic mental syndrome in the elderly patient. In Bellak L, Karasu T (eds). Geriatric Psychiatry. Grune \& Stratton: New York. pp 77-121.

Mayberg HS, Brannan SK, Tekell JL, Silva JA, Mahurin RK, McGinnis S et al (2000). Regional metabolic effects of fluoxetine in major depression: serial changes and relationship to clinical response. Biol Psychiatry 48: 830-843.

McCarron J, Turton D, Pike V, Poole K (1996). Remotelycontrolled production of the $5-\mathrm{HT}_{1 \mathrm{~A}}$ receptor radioligand, [carbonyl- ${ }^{11} \mathrm{C}$ ]WAY-100635, via ${ }^{11} \mathrm{C}$-carboxylation of an immobilized grignard reagent. J Labelled Compds Radiopharmacol 38 : 941-953.

Meltzer C, Drevets W, Price J, Mathis C, Lopresti B, Greer P et al (2001). Gender-specific aging effects on the serotonin $1 \mathrm{~A}$ receptor. Brain Res 895: 9-17.

Meltzer CC, Leal JP, Mayberg HS, Wagner HJ, Frost JJ (1990). Correction of PET data for partial volume effects in human cerebral cortex by MR imaging. J Comput Assist Tomogr 14: 561-570.

Meltzer C, Kinahan P, Nichols T, Greer P, Comtat C, Cantwell M et al (1999). Comparative evaluation of MR-based partial volume correction schemes for PET. J Nucl Med 40: 2053-2065.

Niewenhuys R, Voogd J, van Huijzen C (1981). The Human Central Nervous System. Springer-Verlag: Berlin.

Osterlund M, Halldin C, Hurd Y (2000). Effects of chronic 17betaestradiol treatment on the serotonin $5-\mathrm{HT}(1 \mathrm{~A})$ receptor mRNA and binding levels in the rat brain. Synapse 35: 39-44.

Palego L, Marazziti D, Rossi A, Giannaccini G, Naccarato A, Lucacchini A et al (1997). Apparent absence of aging and gender effects on serotonin 1A receptors in human neocortex and hippocampus. Brain Res 758: 26-32.

Parsey RV, Oquendo MA, Simpson NR, Ogden RT, Van Heertum $\mathrm{R}$, Arango $\mathrm{V}$ et al (2002). Effects of sex, age, and aggressive traits in man on brain serotonin 5 -HT1A receptor binding potential measured by PET using [C-11]WAY-100635. Brain Res 954: 173-182.

Parsey RV, Slifstein M, Hwang DR, Abi-Dargham A, Simpson N, Mawlawi $\mathrm{O}$ et al (2000). Validation reproducibility of measurement of 5-HT1A receptor parameters with [carbonyl- $\left.{ }^{11} \mathrm{C}\right] \mathrm{WAY}-$ 100635 in humans: comparison of arterial reference tisssue input functions. J Cereb Blood Flow Metab 20: 1111-1133.

Pazos A, Probst A, Palacios J (1987). Serotonin receptors in the human brain-III. autoradiographic mapping of serotonin-1 receptors. Neuroscience 21: 97-122.

Rabiner EA, Bhagwagar Z, Gunn RN, Sargent PA, Bench CJ, Cowen PJ et al (2001). Pindolol augmentation of selective serotonin reuptake inhibitors: PET evidence that the dose used in clinical trials is too low. Am J Psychiatry 158: 2080-2082.

Rabiner EA, Gunn RN, Wilkins MR, Sargent PA, Mocaer E, Sedman E et al (2000). Drug action at the 5-HT(1A) receptor in vivo: autoreceptor and postsynaptic receptor occupancy examined with PET and [carbonyl-(11)C]WAY-100635. Nucl Med Biol 27: 509-513.

Rabiner E, Messa C, Sargent P, Husted-Kjaer K, Montgomery A, Lawrence A et al (2002). A database of [(11)C]WAY-100635 binding to $5-\mathrm{HT}(1 \mathrm{~A})$ receptors in normal male volunteers: normative data and relationship to methodological, demographic, physiological, and behavioral variables. Neuroimage 15: 620-632.

Sargent PA, Kjaer KH, Bench CJ, Rabiner EA, Messa C, Meyer J et al (2000). Brain serotonin1A receptor binding measured by positron emission tomography with $\left[{ }^{11} \mathrm{C}\right] \mathrm{WAY}-100635$ : effects of depression and antidepressant treatment. Arch Gen Psychiatry 57: $174-180$.

Smith S (2002). Fast robust automated brain extraction. Hum Brain Mapping 17: 143-155.

Stahl S (1992). Serotonin receptors and the mechanism of action of antidepressant drugs: postmortem, platelet, and neuroendocrine 
studies in depressed patients. In Stahl S, Hesselink J, Gastpar M and Traber J (eds). Serotonin $1 A$ Receptors in Depression and Anxiety. Raven Press: New York.

Stahl S (1994). 5HT1A receptors and pharmacotherapy. Is serotonin receptor down-regulation linked to the mechanism of action of antidepressant drugs? Psychopharmacol Bull 30: 39-43.

Stahl S, Hauger R, Rausch J, Fleishaker J, Hubbell-Alberts E (1993). Down regulation of serotonin receptor subtypes by nortriptyline and adinazolam in major depressive disorder: neuroendocrine and platelet markers. Clin Neuropharmacol 16(Suppl 3): 19-31.

Stockmeier C, Shapiro L, Dilley G, Kolli T, Friedman L, Rajkowska G (1998). Increase in serotonin-1A autoreceptors in the midbrain of suicide victims with major depression-postmortem evidence for decreased serotonin activity. J Neurosci 18: 7394-7401.

Tauscher J, Verhoeff NPLG, Christensen B, Hussey D, Meyer J, Kecojevic A et al (2001). Serotonin $5-\mathrm{HT}_{1 \mathrm{~A}}$ receptor binding potential declines with age as measured by $\left[{ }^{11} \mathrm{C}\right] \mathrm{WAY}-100635$ and PET. Neuropsychopharmacology 24: 522-530.

Tsukada H, Kakiuchi T, Nishiyama S, Ohba H, Harada N (2001). Effects of aging on 5-HT(1A) receptors and their functional response to 5-HT(1a) agonist in the living brain: PET study with [carbonyl-(11)C]WAY-100635 in conscious monkeys. Synapse 42: $242-251$

Underwood M, Khaibulina A, Ellis S, Moran A, Rice P, Mann J et al (1999). Morphometry of the dorsal raphe nucleus serotonergic neurons in suicide victims. Biol Psychiatry 46: 473-483.

Venero J, de la Roza C, Machado A, Cano J (1993). Age-related changes on monoamine turnover in hippocampus of rats. Brain Res 631: 89-96.

Watson C, Newport D, Casey M, DeKemp R, Beanlands R, Schmand M (1997). Evaluation of simulation-based scatter correction for 3D PET cardiac imaging. IEEE Trans Nucl Sci 44: 90-97.

Weinhard K (1998). Applications of 3D PET. In Bendriem B, Townsend D (eds). The Theory and Practice of $3 D$ PET. Kluwer Academic Publishers: Boston. pp 133-167.

Woods RP, Grafton S, Watson J, Sicotte N, Mazziotta J (1998). Automated image registration: II. Intersubject validation of linear and non-linear models. J Comput Assist Tomogr 22: 153-165. 